\title{
DESIGNATED HITTERS, PINCH HITTERS, AND BAT BOYS: JUDGES DEALING WITH JUDGMENT AND INEXPERIENCE, CAREER CLERKS OR TERM CLERKS
}

\author{
DONALD W. MOLLOY*
}

Chief Justice John Roberts famously analogized judging to umpiring at his confirmation hearing before the Senate Judiciary Committee. He declared, "Judges and justices are servants of the law, not the other way around. Judges are like umpires. Umpires don't make rules; they apply them." Of course, the Chief Justice did not describe how judges, like umpires, apply the strike zone. But he did note that the role of umpires and judges is to make sure everyone plays by the rules. With his characteristic wit he added "Nobody ever went to a ball game to see the umpire."1 In this paper I make an equally weak analogy to baseball and how the judge utilizes law clerks as designated hitters, pinch hitters, or bat boys. Lawyers do not go to court to see the designated hitter, the pinch hitters, or the bat boys, yet the relationship of the judge and his or her law clerks raises an interesting question of going to the "ball game to see the umpire."

\section{I}

INTRODUCTION

The role of the law clerk is directly related to the court and the judge for whom the clerk works. ${ }^{2}$ August is usually when new law clerks start work. The phenomenon is described as follows:

It is all too obvious that young clerks, whose only experience is the sometimes unreal world of the academy, are persuading judges of matters that the litigating parties have never had an opportunity to address and expose. Indeed, before receiving the court's opinion the litigating parties do not even know that the matters are being considered, nor do they know that a clerk holds the beliefs that ultimately are used against them. ${ }^{3}$

Copyright $\odot 2019$ by Donald W. Molloy.

This article is also available online at http://lcp.law.duke.edu/.

*United States District Judge for the District of Montana. This paper has enjoyed significant editing by three of my law clerks, Samantha Stephens, Stephanie Holstein, and Hope Staneski. Each of them has contributed not only to the effort to convert a thesis to an article, but all of them have been contributors to the daily work of a federal district court. I am indebted to each of them for their help

1. Roberts: "My Job is to Call Balls and Strikes and not to Pitch or Bat," CNN (Sept. 12, 2005), http://www.cnn.com/2005/POLITICS/09/12/roberts.statement/ [https://perma.cc/H8R9-9MVZ].

2. The role of the clerk varies considerably and is defined by the position occupied, i.e., Supreme Court law clerk, Court of Appeals law clerk, District Court law clerk.

3. Lawrence R. Velvel, Introduction, in 3 THE LONG TERM VIEW: A J. OF INFORMED OPINION 5 (Spring 1995). 
There is a wealth of literature on the role and influence of the Supreme Court law clerk from an ideological perspective. ${ }^{4}$ There is also material regarding the role of law clerks on the courts of appeals, which looks at the ideological compatibility with the hiring judge as well as the potential influence of law clerks in the decision-making process. ${ }^{5}$ However, there is little literature concerning the role and influence of law clerks in the federal district courts. ${ }^{6}$ But, regardless of the court, there is a general notion that the first individual in the judicial decisionmaking process to look at an issue or legal problem can assert significant influence on the case outcome. ${ }^{7}$ Judge Richard Posner acknowledged this when he noted "it is generally true that whoever does the basic drafting of a document-a judicial opinion or anything else-will have a big impact on the final product." ${ }^{\prime}$ That impact is magnified by the litigious nature of American society. ${ }^{9}$ The idea suggests that every issue that cannot be resolved by the political process ends up being resolved by the courts. This provides ammunition for the ideological and political arguments about the role of the courts generally in our constitutional democracy. Implicit in these arguments is the idea that it is the judge who writes and decides. ${ }^{10}$ But the literature that analyzes the actual decision-making process, whether in state or federal court, does not necessarily address the judge as writer, particularly in the federal district court. ${ }^{11}$

4. See, e.g., Todd C. PePPERS, COURTIERS Of THE MARBLE PALACE: THE Rise AND INFLUENCE OF THE SUPREME COURT LAW CLERK (Stanford Univ. Press 2006).

5. See, e.g., JOHN BILYU OAKLEY \& ROBERT S. THOMPSON, LAW CLERKS AND THE JUdiCIAL PROCESS: PERCEPTIONS OF THE QUALITIES AND FUNCTIONS OF LAW CLERKS IN AMERICAN COURTS (Univ. of Cal. Press 1980); Velvel, supra note 3.

6. OAKLeY \& ThOMPSON, supra note 5, at 7; G. Mitu Gulati \& Richard A. Posner, The Management of Staff by Federal Court of Appeals Judges, 69 VAND. L. REV. 479, 482, 496 (2016); Todd C. Peppers, Michael W. Giles \& Bridget Tainer-Parkins, Inside Judicial Chambers: How Federal District Court Judges Select and Use Their Law Clerks, 71 ALB. L. REV. 623 (2008).

7. OAKLEY \& THOMPSON, supra note 5, at 102-03; Rick A. Swanson \& Stephen L. Wasby, Good Stewards: Law Clerk Influence in State High Courts, 29 JUST. SYS. J. 24, 34 (2008); Lawrence R. Velvel, Maintaining Control of the Judiciary: An Interview with Judge Abner J. Mikva, 3 THE LONG TERM VIEW: A J. OF INFORMED OPINION 9 (Spring 1995) [hereinafter Judge Mikva].

8. Judge Richard A. POSNer, The Federal COURTS: CRisis AND ReForm (Harv. Univ. Press 1985), as reprinted in "The Rise of the Law Clerk," 3 THE LONG TERM VIEW: A J. OF INFORMED OPINION 25 (Spring 1995).

9. Judge Posner observed, "The problem is that, except in the Supreme Court, which controls the major part of its workload (the hearing and decision of the cases that it accepts for plenary review), the caseload per federal judge has risen to the point where very few judges, however able and dedicated, can keep up with the flow without heavy reliance on law clerks, staff attorneys, and sometimes externs too." Id. at 23 .

10. "The public naively assumes that it is the judges who decide cases and explain their results.... [A] clerk ought to be someone whose work is not separate and apart from what the judge is doing, but rather an assistant in a decisional process that is truly the judge's." John G. Kester, The Law Clerk Explosion, 3 THE LONG TERM VIEW: A J. OF INFORMED OPINION 16 (Spring 1995). See also Gulati \& Posner, supra note 6, at 481-82 (describing that most appellate judges consider that doing all their own research and writing is a thing of the past); David Lat, How Should a Judge Be: In Defense of the Judge as CEO, 69 VAND. L. REV. EN BANC 151, 156-65 (2016) (defending the judicial management model in which law clerks draft and judges edit opinions).

11. But see Joel COHEN, BLINDFOldS OfF: Judges on How THEY DECIDE (A.B.A. 2014); LeE Epstein, William M. LANDes \& Richard Posner, The Behavior of Federal Judges, A 
The number of cases in the courts compared to the number of judges leads one to ask: how does a particular judge work so that fair consideration by the judge is given to all the participants? ${ }^{12}$ The Herculean task of reading and deciding at the district court is almost impossible without the aid of law clerks. Because the reading and writing of the district court is cabined both by time constraints and the volume of material to be consumed, the law clerk becomes central to this process. ${ }^{13}$ Paradoxically, the number of law clerks available to help a judge is inversely related to the number of cases the judge must decide. ${ }^{14}$ This may say something about the priority of factual truth and legal discipline. Nevertheless, it is clear that law clerks, whether term or career, are critical to judicial decision-making. How, then, do judges deal with the unique role that law clerks play? Are the clerks substituting for the judge as the designated hitter? Does the judge use the clerk as a pinch hitter, relying extensively on the clerk in certain situations? Or, does the judge see the clerk as a bat boy whose only role is to make sure the judge has the necessary tools with which to hit?

II

\section{THE ROLE OF LAW CLERKS IN THE COURTS}

After noting the workload of district court judges, I will explore how the lack of experience among clerks causes judges to carefully weigh the pros and cons of term clerks and career clerks before choosing how to staff their chambers. In doing so, I conducted interviews of several federal district court and magistrate judges for this article.

Understanding the role of the clerk first requires understanding the role of the judge. District court judges supervise the trial of facts before juries, act as fact finders, and decide questions of law upon various motions. District court judges also manage chambers and frequently serve on various committees, national and local. The workload is heavy and it would be impossible for one person to efficiently accomplish all of this work and write all of the opinions. ${ }^{15}$ But there is an additional role for judges that relates to their law clerks. They are also teachers, for both the larger world and those who work with them. ${ }^{16}$ Many judges disagree about these responsibilities and view their duties, not as pedagogical, but as managers for efficient case resolution.

TheOretical \& EMPIRICAL Study of RATIONAL Choice (Harv. Univ. Press 2013); DAvid M. O'Brien, Judges on Judging: Views From the Bench (3d ed., Cong. Q. 2008); Richard A. PosNer, REFLECTIONS ON JUdGING (Harv. Univ. Press 2013). With the exception of some of Judge Posner's writing, there is little reference in these books to the role that law clerks play in the decisionmaking process.

12. For example, in 2014 , the federal district courts resolved 370,013 total cases $(303,820$ civil and 66,193 criminal). Those numbers are typical.

13. Judge Mikva, supra note 7, at 12 ("Courts would not function nearly as well if they didn't have clerks.").

14. Gulati \& Posner, supra note 6, at 496 (explaining that district court judges have heavier caseloads and smaller staffs than circuit court judges).

15. See OAKLEY \& THOMPSON, supra note 5, at 98.

16. See Joseph D. Kearney, A Truth About Career Law Clerks, 98 MARQ. L. REV. 13, 19 (2014). 
Often the trial judge, with the aid of the law clerks, is left pondering what the law is given the facts presented in the case and the issues the court is asked to resolve. ${ }^{17}$ Too frequently the quality of the legal work at the trial level is subpar when contrasted with the quality of most legal work at the courts of appeals. This situation can lead to the following problem: "If they [law clerks] lack the time, they will have to depend on the briefs; and at least at the district court and court of appeals levels this will mean, all to [sic] often, dependence on inadequate research by the lawyers." 18

The district court must keep litigation on schedule while simultaneously deciding cases. The trial judge has the responsibility to provide answers, not theory, to the litigant's factual and legal disputes. "A district judge cannot hide behind his law clerks in the actual conduct of a trial. He must rule on matters on the spot, and if he is incompetent this will show up much faster than incompetence on the appellate bench." ${ }^{19}$

Due to the caseload of many district court judges, the experience of the new district court law clerk should be a concern in the influence the clerk may have on the district judge's decision-making. If the judge relies on early work of a new law clerk, without a degree of skepticism, is the judge using the clerk wisely? This is where the question of how the district judge staffs the judge's chambers arises.

Historically, every clerkship was shorter in tenure than that of the judge, a fact serving to keep "the roles of clerk and judge in proper perspective." ${ }^{20}$ This has changed somewhat with the advent of career clerks. Importantly, judges who employ career clerks all noted that a "career" does not equate to lifetime tenure. Many of the clerks who were career clerks served terms of ten years or less. In my interviews, the longest serving career clerk was thirty-four years, the shortest was four years. The judge always has the option to change from a term clerk to a career clerk when a mutually beneficial relationship with an existing term clerk comes along. The Judicial Conference policy proposed requiring term clerking experience before promotion to career clerk status. ${ }^{21}$ This emphasized the mentoring relationship between the new lawyer and the experienced judge. ${ }^{22} \mathrm{But}$ there is now another relationship to consider, the relationship between the career

17. This is a personal observation based on sitting as an appellate judge and as a trial judge in different circuits.

18. Posner, supra note 8, at 27.

19. Id. at 30 .

20. OAKLEY \& THOMPSON, supra note 5 , at 34 .

21. Summary of the Report of the Judicial Conference Committee on Judicial Resources, DT: Committee Report, CR-JUDRES-SEP 07 (September 2007). The report recommends no more than one career law clerk per judge and limits the period during which a term clerk can serve to no more than three years. The report recommends that if career clerks are to be hired they must have term clerk experience in the same chambers.

22. Most judges believe mentoring is a part of their job description. "[J]udges view law clerks not only as important subordinates but as fledging [sic] lawyers to whom a duty was owed to mentor and educate." Peppers et al., supra note 6, at 637. For a critical view of the close relationships some judges cultivate with their law clerks, see Paul Horwitz, Clerking for Grown-Ups: A Tribute to Judge Ed Carnes, 69 ALA. L. REV. 663 (2018). 
clerk and the judge. "The qualities and motivation of law clerks differ markedly with their tenure." 23 The relationship of the career clerk and the judicial officer is often more akin to a law firm where there are partners, junior partners, associates, and paralegals. Career clerks are selected for reasons of efficiency, not necessarily creativity; practical court experience as a clerk and evidence of productivity in a bureaucratic environment play a more important role than the notion of mentoring. ${ }^{24}$ What this dynamic exposes is the tension between the judge who mentors lawyers for public service, and the judge who hires for efficiency and compatibility. Each has an impact on how new clerks are treated and consequently on the judge's decision to choose term or career clerks. ${ }^{25}$

Though different courts follow different staffing practices, district courts occasionally take clerks with experience, but usually take them straight from law school. District courts generally have two clerks, three if the judge decides a Judicial Assistant (JA) ${ }^{26}$ is unnecessary. District judges staff with either two term clerks or one term and one career. Those with two term clerks typically stagger their start dates.

The primary role of any trial court clerk is to assist the judge in operating chambers efficiently under considerable time constraints and tremendous workloads. The principal duties of the law clerk include conducting legal research, editing, drafting opinions, checking citations, preparing memoranda, doing legal analysis, and attending oral arguments. ${ }^{27}$

Some judges perceive that many smart new lawyers do not have the necessary judgment to perform the tasks and responsibilities given them without extensive training in chambers. This problem is particularly acute when the new law clerk first assumes his or her position with the judge. This is where the "August Effect" comes into play. Incidentally, the medical profession has identified the "July Effect," which, in principle, is the same. July is a time where most mistakes in teaching hospitals occur when the new "doctors" or interns move from a position focused on education to the position of first-year residents. ${ }^{28}$ Another analogy is flight training, which exposes the problem of relying on knowledge alone as the

23. OAKLEY \& THOMPSON, supra note 5, at 34, 34 n.2.93.

24. Id. at 34. The appeal of the career clerk is experience and efficiency, but there is a compromise with the liveliness lost with the frequent arrival of a new term clerk. Id. at 31.

25. "Clerks with longer-term appointments would surely become more efficient and knowledgeable. Extending clerks' tenure, however, might also have drawbacks more far-reaching than shrinking the number of clerkship openings. For example, clerks hired for longer terms might be more likely to exercise undue influence with their bosses." Sean Donahoe, Behind the Pillars of Justice: Remarks on Law Clerks, in 3 THE LONG TERM VIEW: A J. OF INFORMED OPINION 78 (Spring 1995).

26. The Judicial Assistant is one of three positions a district judge is allotted for staffing chambers. The JA is in essence an office manager. There is a salary cap on the position. Some judges have hired three law clerks and eliminated the JA position.

27. Off. of Career Servis., Hofstra Univ. Sch. OF L., Post-Graduate Judicial CLERKSHIP HANDBOOK 5 (2005).

28. See, e.g., David P. Phillips \& Gwendolyn E.C. Barker, A July Spike in Fatal Medication Errors: A Possible Effect of New Medical Residents, 25(8) J. GEN. InTERnAl MED. $774-79$ (2010); David Mikkelson, Would July to Me?, SNOPES (July 16, 2015), https://www.snopes.com/fact-check/would-julyto-me/ [https://perma.cc/HFL7-Q7HF]. 
criteria in measuring the ability to accomplish sophisticated and difficult tasks in the absence of experience. Without skill and experience, in addition to knowledge, judgment is much more likely to be faulty or in error. Whether it is the "August Effect" in law, the "July Effect" in medicine, or a disastrous aircraft incident, there is a need to recognize the reality of inexperience and to incorporate specific training or direction from the judge to minimize the impact that a new law clerk may have on the judge's decision-making process.

Judgment in any profession or activity is specifically related to a series of evaluations that are made over a period of time. Good judgment serves the positive aspects of the undertaking, and it is a key component of what makes a good law clerk. Brand new law clerks who are unaware of the complications of procedural law and substantive questions but who relish the opportunity to question the work of lawyers are likely to provide a judge advice that should be viewed skeptically. ${ }^{29}$ Judgment is often equated with common sense. However, common sense usually derives from experience, and it is not a part of procedural or substantive law nor the traditional world of law. Legal judgment recognizes and analyzes available authority as applied to facts, followed by a rational evaluation of the alternatives available to making a correct legal decision. ${ }^{30}$ As one judge put it: "term clerks are not worth a hoot because they have no wisdom."

Significantly, all interviewed judges believe that the "August Effect" is real. One judge said it is like the lyrics of a country western song, "I wish I knew then what I know now that I didn't know then." A new law clerk generally has anxiety and an uncertainty that the judge needs to address. This stems from lacking real life court experience.

As a consequence, new law clerks need greater supervision and more feedback than either an experienced law clerk or a career clerk. Judges need to provide more hands-on supervision and training with a new term clerk. Treating a new term clerk as an equal to the second-year term clerk or the career clerk is a mistake. As discussed below, there are strategies judges use in anticipation and recognition of the "August Effect" to minimize the consequences of the new term clerk who can be accurately described as a deer in the headlights.

29. By analogy, "Airmen who are either unaware of the potential hazards or who actually relish the opportunity to take unnecessary risks are those likely to be involved in judgment-error accidents." FED. Aviation Admin., Transp. CAN. \& GEn. AVIATIOn MFG. Ass'N, JudgMEnt Training ManuAL FOR STUDENT PILOTS 2.

30. See id. at 3 (This description is an adaptation of the argument regarding judgment involved in training aviators). 
III

INTERVIEWS AND FINDINGS

\section{A. Methodology}

I interviewed 26 federal district court and magistrate judges about the "August Effect" and how it impacts the choice to use career or term clerks in their chambers. Each of the 26 judges was what I have labeled a "switcher," i.e., a judge who either started with career clerks and switched to term clerks, or a judge who started with term clerks and switched to career clerks. Other than that, the judges had varied experiences and backgrounds. The interviewees included male and female judges; active, senior, and retired judges; and Carter, Reagan, ${ }^{31}$ H.W. Bush, Clinton, and W. Bush appointees, with six years to forty years' experience on the federal bench. The judges' previous experience included private practice in civil defense firms, public service including criminal defense work, plaintiff's litigation, and work as a sole practitioner. Six of the interviewees had served in the military, including two as JAG officers. Four of the interviewees were district court judges who had first served as magistrate judges, and five were district court judges who had first served as state court judges. Four of the interviewees had themselves served as law clerks to federal judges.

To make sure I received candid answers, the interviews were conducted according to strict confidentiality terms. Identifying information, including the date, place, and time of the interviews, has been excluded from the following discussion.

\section{B. Law Clerks and Their Work in Chambers}

\section{Hiring Process}

Many of the judges interviewed deemed $\mathrm{OSCAR}^{32}$ as not very helpful because it provides the judge too much information. The general practice followed by the judges is to have existing clerks narrow the field of potential clerks to a manageable number, and the judge weeds the potential law clerk list to those the judge wants to interview. The judges noted that almost all who are interviewed are qualified for hire, leaving the judge to make what is frequently a very personal choice. Many of the judges look to local law schools. Grades are important, but they are not the only qualifier. Grades are mostly useful as a threshold factor in the selection of new term clerks. One judge indicated that

31. The judges appointed by President Reagan each made a point of telling the story of the individual call they received from the President, asking if they would permit the President to submit his or her name as a prospective Article III judge. None of the judges appointed by the other Presidents received the honor of such a call. One judge had prepared a secretary, soon to be JA, to capture the call on film. As the nominee stood at attention when the President called, the office quieted and listened as the President asked his nominee's permission to submit the nominee's name to the Senate. All went well but for the duty assigned to the soon-to-be JA. The secretary forgot to turn on the camera.

32. OSCAR (Online System for Clerkship Application and Review) is the computerized database for clerk applications. 
grades are an important indication of the ability to communicate while simultaneously being a reflection of intelligence. Several judges thought that unless the person was at or near the top of the class, the applicant was not a good candidate for hire.

When first hiring term clerks it is common for the judge to go to law school deans and friends to find potential applicants. Some judges go to other judges seeking advice about hiring clerks and deciding if the clerk should be term or career. ${ }^{33}$ Several of the interviewed judges teach at a law school. Teaching provides an opportunity to observe the work of prospective clerks, to be exposed to their ability to think and analyze, and is, as one judge stated, like having a "farm team" to find clerks for the big leagues. Other judges looked to interns/externs as a pool for clerks. None of the judges seemed wedded to "elite" graduates to serve as clerks at the district court. While none of the judges said they looked for clerks with compatible ideological views to their own, at least one judge had a preference to hire a term clerk whose ideological views conflicted with his own. He noted it kept him "honest" and objective. The diverse perspective enured to the benefit of his chambers.

\section{Work Assignments}

The most common way to assign work in chambers, regardless of whether the judge has term clerks, career clerks, or a combination of both, is to assign case work to either law clerk based on an odd-even rule. That is, one law clerk is assigned all the even-numbered civil and criminal cases, and the other clerk is assigned all the odd-numbered cases. Some judges are very hands-on in assigning cases and are adept at using the Case Management/Electronic Case Filing $(\mathrm{CM} / \mathrm{ECF})$ electronic case filing system. When judges are tech savvy, they will usually triage how work is assigned. Judges may do some orders or docket management by text order themselves. They determine the complexity of a new case and may specifically assign the work to the career clerk based on a determination of how long the case may take and how difficult or novel the issues in the case might be. When judges have a career clerk and a term clerk, attention is paid to the likely time needed to resolve the case from filing to trial and judgment. An effort is made to avoid assignment of complex or extended cases to term clerks because they may end their service before the case is over, which means duplication of work. This kind of triage by judges is the secondary level of work assignment that complements the odd-even system. Other judges rely on the JA to act as the office administrator and look to the JA to monitor chambers work.

One of the roles assigned to a career clerk is often to do an additional level of triage to refine assignments to the term clerk and to the interns/externs working in chambers. When this happens, the career clerk is also serving in a mentor role, assigning term clerks and interns/externs work in the areas of their known

33. Under current Judicial Conference policy, a term clerk's tenure is limited to four years and each chambers is limited to one career clerk. 
interests. There is an expectation among some judges that, regardless of the assigned work, all of the clerks share their thinking on each of the cases and issues before the court, particularly in civil cases. One judge's career clerk established a "peer review" by all of the clerks and externs in chambers to review each opinion, order, or bench memo before it is given to the judge.

Regardless of the way work is initially assigned, all of the judges have a particular way that the law clerks work: as one judge noted "there are no universals." For instance, before a hearing the judge may get a notebook or packet from the law clerk. The notebook contains the pertinent pleadings and briefing together with a draft order. The judge may not read the draft order before the hearing, or if no hearing, before reading the briefs. Some judges outline the arguments of the parties and will not read any proposed order or opinion until after the hearing on a motion. Because of the volume of work, several judges rely on the law clerk's work and may not read briefs filed by counsel, instead being informed by bench memos, law clerk discussions, and the law clerk's draft orders. All of the judges work collegially with the law clerks on analyzing the arguments and positions of the parties. This is consistent with the findings of Oakley \& Thompson where they noted that, at least in part, draft opinions by law clerks serve first as a discussion piece to enlighten the judge. ${ }^{34}$ One judge thought "the lawyers would be surprised to find out how much law clerks are actually doing" on motions the judge decides.

Ultimately, the most common chambers arrangement for clerks falls into one of two categories. The first is the judge who has two term clerks staggered with two-year terms so that the rotation means there is always one senior clerk to help mentor the new term clerk. The other chambers setup is one career clerk and one term clerk, again ensuring that there is one person who knows the ropes and can mentor the new term clerk and any interns/externs. ${ }^{35}$ Several of the judges have or had two career clerks. Up until 2007, Article III judges could offer each clerk the salary and benefits of career status. In September 2007, the Judicial Conference adopted the recommendations of the Committee on Judicial Resources to eliminate Leave Act coverage for non-career clerks, to limit judges to one career clerk per chambers, and to place a four-year limit on the tenure of a term clerk. Because of the policy change, judges who had two career clerks could seek an "exception" to continue staffing chambers with two career clerks so long as the judge applied for the exception before January 30, 2009. Consequently many judges grandfathered the two career clerks, including some

34. See OAKLEY \& THOMPSON, supra note 5, at 15 .

35. There is no salary difference based upon the status of the clerk as term or career. The difference comes from longevity. A term clerk is limited to four years. A term clerk starting right after law school graduation starts at a grade 11 . The term clerk can be promoted to grade 12 after one year. If the term ends at two years there are no more raises. If the clerk stays another year a performance raise can be granted by the judge to a grade 13. The top salary for a career clerk is grade 14 but it takes twenty-two years for a career clerk to reach that salary. 
judges interviewed for this paper. ${ }^{36}$ The interviews established two judicial philosophies on the kinds of law clerks a judge should retain. One view says a judge should always have at least one career clerk. The other view was expressed by a senior judge who noted "career clerks are the worst thing to happen to the judiciary."

\section{Clerks' Work on Different Types of Cases}

Judges express great confidence in a career clerk's work on complex cases such as environmental, multidistrict litigation, or patent cases. This confidence rests on the length of time the judge has worked with the career clerk. It comes from the judge who has learned to appreciate the career clerk's thinking and writing skills. The career clerk in such instances has usually captured the ability to write in the judge's voice. Judges who have been with career clerks for any appreciable time find that the clerk "thinks like I do," capturing the judge's style and expression. Two of the judges who rely on long-term career clerks noted that in exchanging drafts of opinions there is frequently an exchange of "external comments" ${ }^{\prime 37}$ to see if one or the other is actually reading what is written.

Paradoxically, with the notable exception of longevity, the judges reported no real difference in the work of career and term clerks. This observation may be accurate if it references only the structure of legal writing, but it undermines the arguments made in favor of career clerks over term clerks. Principally, the proposition challenges the argument that the benefit of a career clerk is knowledge of how the judge works, the capture of the judge's voice in writing, and avoidance of the "August Effect."

Many judges believed that non-jury cases require the presence of a law clerk. Judges use the law clerk as a scrivener for proposed findings of fact and conclusions of law and often discuss the credibility of witnesses and the evidence with the law clerk before rendering judgment. Non-jury trials are a very collaborative process that involves debate between the law clerk and the judge to help refine the judge's thinking. It is like a mini advisory jury trial, ${ }^{38}$ but ultimately it is the judge who makes the call, including on issues of credibility and the significance of other evidence. ${ }^{39}$ The process is judge directed.

There is a marked difference in criminal cases as opposed to civil cases in how the law clerks are used, but term clerks and career clerks are generally utilized the same. The distinction seems to be the judge's personal experience at the bar or on the bench. Judges who were magistrate judges, or state trial judges, do not rely much on clerks when it comes to criminal matters. The reason is that the judge has "been there, done that" so many times that the judge has confidence

36. See Memo from James Duff to All United States Judges, Re: Chambers Law Clerk Employment Policies (Action) (January 6, 2009).

37. One judge referred to this process as giving alerts to the law clerk, or to the judge, when a zinger is put in the opinion. A note will accompany the text asking, "Is this a good idea?" Other judges call these statements or comments "judicial excited utterances." See Fed. R. Evid. 803(2).

38. See Fed. R. Civ. P. 39(c).

39. See Fed. R. Civ. P. 52(a)(1). 
that no help is needed from the clerks, especially term clerks who do not have any experience. For several judges, it is an extension of prior state trial experience where the judge had no law clerk and was not required to give reasoned written opinions. When written opinions are produced, the law clerks edit what the judge has written for grammar, citations, logic, and analysis.

Another area where judges are disinclined to rely on the help of clerks, career or otherwise, is in discovery disputes. As with criminal cases, there is comparatively little court writing and consequently less reliance on clerks. Some judges cut off discovery disputes by making themselves available by telephone to nip the fight in the bud. However, there were a few judges who used career clerks as nominal avatars for the judge when dealing with discovery problems. This practice is based on the belief that the career clerk knows the judge so well, and knows how the judge thinks, that the career clerk can talk to the lawyers having discovery difficulties and generally know what the judge is likely to do. None of the judges vested this kind of responsibility with term clerks.

Judges often do not have a law clerk review the findings and recommendations of the magistrate judge, but perform that review themselves. In the words of one judge, "I wasn't going to have a law clerk review the Magistrate Judge's work." This practice is not universal. Indeed, the practice is at odds with the procedure that courts of appeal follow where law clerks are generally reviewing the work of experienced trial judges and magistrate judges, even when the law clerk has no practical experience or judgment.

Nonetheless, there is one aspect of the law clerk's job that falls squarely within the judge's role: sentencing. It is the one thing that judge's do entirely on their own, the part of the job that a law clerk cannot help with. Sentencing is the stuff of working weekends and nights to understand who the defendant is, what the crime is, and how the sentence will impact the various entities that the judge must consider when rendering judgment about another human being. Taking liberty is not easy, and it is a topic about which judges do not consult their law clerks, regardless of whether the clerk is term or career. Sentencing may be the closest thing to the theoretical idea of a judge that does all of his or her own work..$^{40}$ Even those judges who do not regularly read the lawyer's briefing in civil cases read every document in the court file before imposing sentence.

I asked each of the judges interviewed what he or she felt was the most difficult task for a judge. One hundred percent of the judges answered with one word: sentencing. All of the judges in one way or another expressed the view that not only is sentencing the most difficult task of a district judge, but that it is supposed to be the hardest thing a district judge does. If it ever gets easy, the judges uniformly stated that "it is time to retire or move on." One judge said that sentencing is the most difficult and lonely task a district judge performs:

40. See Peppers et al., supra note 6, at 626 n.15 ("Representative David K. Carter of Ohio scornfully suggested that the justiceswere asking Congress [for law clerks so] 'that they might be furnished with auxiliary brains, to do their thinking ... which now God knows, they did not do."”). 
For me it was always sentencing. I am playing a demigod when dealing with the life of a human being. I couldn't afford to kick the dog at home because I was having a bad morning and go into the courthouse and kick some poor soul that I'm sending to prison. I wanted to make sure thatI was focused, that I was balanced; balanced between justice, punishment, compassion, mercy. Balanced. It's hard. It's a lot harder to have balance as a judge than it is to say it. You know exactly what I'm talking about, and you anguish about some of the sentences. You anguish about how it affects the victims. You anguish about what society is going to say about this. Is it appropriate deterrent for the crime that was committed? Is it really just to send a 19-year-old, pock-faced, meth-addicted kid to prison because she had a boyfriend that beat the crap out of her to sell his drugs? And how long are you going to do it?

Many of the judges said that if sentencing is easy the district judge has lost sight of the Constitutional power being exercised. Preparation to sentence an individual is the one matter that takes the most time and thought of the judge. It is the task that causes the most wear and tear on the judge mentally and physically. It is an extremely difficult exercise of judgment that is emotionally draining; there are very few sentencings where the judge says, "I got that right, and the sentence is a just one." Mandatory minimum sentences frequently put the judge in tension with the judge's idea of "justice." The rule of law compels the judge to impose the mandatory minimum sentence even when the judge believes it is wrong. What usually happens in such cases is the judge takes the time to explain to the defendant that the "rule of law" means the sentence must be imposed, even if the sentence is contrary to the judge's sense of justice and a sentence that is "sufficient but not greater than necessary." ${ }^{41}$ Even so, sentencing is a solitary act that-probably more than anything else a judge does-comports with the perception and expectation the public has of "judging." The public, and the bar, want such difficult decisions to come from a judge, not a law clerk, and not even with the influence of a law clerk. The solitary art of sentencing leaves no room for the input of even a career clerk as the Constitutional structure of lifetime appointment assumes that it will be the judge and the judge alone that makes the difficult sentencing decisions, as well as decisions in other cases, which are often controversial.

\section{In the Courtroom}

A significant difference in the role of the term clerk and the career clerk is in their courtroom assistance to the judge. The judges who have career clerks do not insist on the clerk's presence in the courtroom during argument. Frequently the clerk observes and listens to the hearing from chambers. When a case involves a term clerk, the judge usually has the clerk in the courtroom, although this is not universally the case. In either instance, the law clerk's job is to listen, think, and evaluate the arguments made by the lawyers, and think about how an opinion or order might be written. When there is an interesting case, both types of law clerks may be involved not only to help the judge but also to gain experience. The

41. 18 U.S.C. $§ 3553$ (a) ("The court shall impose a sentence sufficient, but not greater than necessary, to comply with the purposes set forth in paragraph (2) of this subsection."). 
benefit is in observing the quality of the lawyers, how complex the issues in a case can get, and in learning what does and does not work.

During a hearing, several of the judges message or email the law clerk, carrying on a conversation about the arguments while they are being made. Having the clerk in the courtroom is viewed as a specific part of the judge's duty as a mentor. It is viewed only as an "interesting opportunity" by judges who are disinclined to view their role as one of mentoring.

There are two schools of thought on having a law clerk, career or term, in the courtroom. One holds it is a useless proposition because the law clerk could be doing meaningful work in chambers with access to audio or video stream from the courtroom. This is an efficiency argument and does not consider the mentoring role the judge plays, particularly with a term clerk. The other school of thought holds that it is beneficial to the law clerk and the judge to have the clerk in the courtroom to observe so as to assist the judge in reaching an informed decision after the hearing. The law clerk has a computer terminal in the courtroom and can do other work, while also providing immediate assistance to the trial judge. The second school of thought is closer to the described role of the judge as mentor with a duty to the bar and public to produce educated trial lawyers and public servants. For many judges, the clerk serves the additional courtroom function as the bailiff for the jury, assisting the judge with quick legal research, and preparing the instruction package for the judge's review and editing.

Another area in the courtroom where term and career clerks are used differently is in preparing jury instructions. Several judges made the distinction between the term and career clerk in preparing instructions; some judges always assign the task of preparing jury instructions to the career clerk. This is because the judge believes the career clerk is familiar with the judge's rules and how the judge wants the instructions prepared. An additional advantage is that the career clerk can anticipate what instructions the judge should give based on past cases. The judges all had different ways of dealing with instructions for jury trials, but the common aspect among the judges was the importance of the law clerk in reviewing, preparing, assembling, and finalizing the instruction packet at the judge's direction. Once the collaboration between the judge and the law clerk in preparing the instruction packet is complete, the judge usually meets with counsel to go over the instruction packet and permit the lawyers to make a record. If there are changes, the law clerk serves as a scrivener taking notes and following the judge's instructions for changes. Notably, the judges who were formerly state trial judges do not use law clerks when it comes to jury instructions - a reflection of having done that part of trial work without law clerks as a state trial judge.

But, an area where term and career clerks perform similar functions is in civil cases. In civil cases, the law clerk - either term or career-and the judge usually brief each other before any hearing. The law clerk has the responsibility to ensure that the judge is up to date on the issues and the law, as well as suggesting 
questions the clerk thinks need to be raised at argument. After argument, the judge usually has a post-hearing discussion with the law clerk to analyze what took place at the hearing and to discuss the possible resolution of the pending issues. This undertaking, in addition to discussing the substantive answer to the legal problem presented in court, is an opportunity for the judge to mentor future lawyers on the professionalism and technique of the various lawyers who presented evidence or argued.

\section{In Chambers}

The greatest variation in the use of law clerks rests in chambers operation. All of the judges use law clerks differently for chambers work, including writing, scheduling, discovery disputes, and delegating work assignments when a career clerk is employed. A prominent concern of all of the interviewed judges is abdication of the adjudicatory function of the judge when long-term career clerks are employed. Several judges indicated that an advantage of the term clerk is the hands-on mentoring required of the judge, minimizing the abdication concern. Those judges with career clerks make the point that in the management of chambers no hierarchy of authority exists. Having said this, there is a recognition that a career clerk is treated differently by those outside of chambers, including members of the clerk of court's staff. Judges are aware of a potential problem that occurs when a career clerk is employed: a pecking order naturally evolves by virtue of longevity. Part of the reason for this informal hierarchy is that the career clerk mitigates the "August Effect" by serving as a junior mentor to the term clerks and the interns/externs.

The law clerk, particularly the career clerk, acts as a conduit for the judge with outside agencies. However, law clerks are usually admonished by the judges that they must keep in mind that the only matters that can be discussed with outsiders are procedures the judges follow. ${ }^{42}$ The law clerks are prohibited from discussing substantive matters, and when a law clerk arrives to begin work the judge advises the clerk of the responsibility to be careful in discussing matters outside of chambers and that, whenever the clerk speaks, the listener hears the judge, not the clerk. One judge tells each new term clerk they will have an irresistible urge to reveal "how important they are in the bar and with the bar." The judge makes the metaphorical point that "loose lips sink ships" and that law clerks are not to discuss in public anything that takes place in chambers. Some judges require law clerks to sign agreements that, in effect, solidify the rule referred to by several judges: "What happens in Vegas stays in Vegas."

42. "Because of the confidential nature of chamber activity, as well as the varying ways in which different judges use their clerks, our knowledge of law clerk duties is somewhat limited. ... [I]t would be unwise to generalize about the duties of district court clerks from a description of appellate court duties. One duty that many judges and clerks acknowledge at all levels has been some drafting of judicial opinions or final orders, though the level of clerk participation varies widely over time as well as across chambers and different types of courts." Peppers et al., supra note 6, at 631.

43. "The majority of the judges who formally discussed confidentiality rules indicated that they adopted the sweeping rule that 'what goes on in the chambers stays in the chambers."' Id. at 636. 
Every judge interviewed emphasized that all term clerks, career clerks, and interns/externs are supposed to verify that they have read and understand the canons of ethics for judges and law clerks.

Most of the judges described their chambers as being "laid back," "collegial," and "informal" with no shouting or screaming even when mistakes are made. Judges want to make chambers a work place where everyone wants to be and where everyone on staff is enthusiastic about being there. For those judges who have kept a staff position filled by a JA, the JA serves as traffic control for chambers. There is nearly unanimous agreement among the judges that if a judge has no JA a career clerk is a necessity. Running a chambers requires an office administrator and a law administrator. In the absence of a JA, the career clerk fulfills those administrative roles.

\section{Writing}

The judges agreed that the ideal writing relationship between the judge and a clerk is based on two factors. First, it is the judge who must retain responsibility for decision-making. Second, the clerk must carry the adversary process into chambers, challenging the judge to justify each aspect of the decision-making process. ${ }^{44}$ The law clerk then makes a significant contribution by drafting part or all of an opinion or order. After a decision is made, judges have a need to delegate writing tasks to the law clerk because of the time constraints that they are under to issue a judgment and move on to the next case. ${ }^{45}$ If there is writing, the general rule is that it needs to be collaborative between the judge and the law clerks. Several of the judges look at draft orders or opinions written by the law clerk before any serious discussion with a law clerk, a practice which raises Judge Posner's concern about the clerk's influence on outcome. The interviewed judges made it clear that the judge decides the case and provides direction on how the outcome should look. ${ }^{46}$ This is so even when a law clerk disagrees. This policy avoids abdication of the judge's duty to decide and deals with the potential inexperience of the assisting law clerk. While the judges generally said there is little difference in the quality of the work done by term or career clerks, assuring this requires that there is closer mentoring of the term clerk until the clerk "learns the ropes."

Judges say there is too much reading for one person to accomplish and at the same time be able to write every order or opinion from scratch. But, there are multiple areas where judges write the first draft instead of clerks. For example, when any issue, particularly in criminal hearings, involves credibility findings the judge often writes the first draft of an opinion or order. The most common

44. See OAKLEY \& THOMPSON, supra note 5 , at 37 .

45. Swanson \& Wasby, supra note 7 , at 38 .

46. Many of the judges interviewed, if not all, expressed concern about abdicating the judge's role. All were concerned with the notion expressed by John G. Kester, who noted: "Overreliance on law clerks injures the judiciary. It encourages bad habits - the tendency of judges to delegate their nondelegable [sic] functions, and the intellectual laziness that comes from knowing that there is someone in the back room who can rationalize any decision." Kester, supra note 10, at 15. 
instance of a judge writing the first draft is if a case or an issue appeals to the judge's curiosity or intellect by virtue of its familiarity or uniqueness. In almost every other instance the law clerk will write the first draft opinion from a bench memo $^{47}$ or from scratch.

Notwithstanding the occasional first draft composed by the judge, writing is generally a collective undertaking, rarely does the judge provide the initial product. Regardless of the method by which chambers produces written opinions or orders, each of the judges employs a procedure that distinctly shows it is the judge who determines and guides the law clerk in the writing that decides motions or cases. Many district judges start out with bench memos written by the law clerk for any particular issue the judge must decide. Then, after some experience with the bench memo practice, judges might prefer a draft order or opinion from the law clerk because experience leads the judge to the conclusion that a bench memo is a waste of the law clerk's time. It is more efficient to edit or work from a draft opinion than it is to work from a bench memo. Other judges believe the bench memo serves the purpose of making the law clerk both summarize arguments and point out authority cited as either controlling or distinguishable. The judge can then rely on the bench memo at hearings and use it as a starting point for editing an opinion or order. Sometimes the bench memo acts as the skeleton for the judge to flesh out when ruling from the bench.

Of the multiplicity of roles law clerks serve in the district court, writing is a critical part of their job. No interviewed district judge or magistrate judge identified himself or herself as a solo writer. But, there is a clear line between the judges who prefer bench memos and those who like draft orders or opinions. This internal operating procedure is one that is dependent on the individual judge's preferences but it is also one that, depending on whether it is a term or career clerk, can have both a downside and an upside. The downside is theoretical in that the first person who looks at an issue will generally dictate the direction of its outcome. ${ }^{48}$ Thus, if the judge is using the clerk to draft orders or opinions instead of bench memos, the career clerk who knows the judge may be in a much better position to accomplish the initial draft than a term clerk. On the other hand, the use of bench memos gives the judge the opportunity to read briefs and then the bench memo to see if the law clerk's analysis comports with the judge's judgment. Even the busiest judges are likely to pick and choose the opinions that they will personally draft. ${ }^{49}$ As previously noted, writing with judges and clerks is

47. A bench memo is a document prepared by a law clerk that outlines the arguments of each party, discusses cited authority, and recommends a ruling to the judge. It can include various information so the judge knows when the issue was fully briefed, the names of counsel, and any pending trial or motions dates.

48. "If the judge just reads the bench memos and doesn't read the briefs [prepared by the lawyers in the case], the law clerk is going to have a lot of influence." Richard A. Posner, Working Within the Confines of Our Current Judiciary: An Interview with Judge Richard A. Posner, in 3 THE LONG TERM VIEW: A J. OF INFORMED OPINION 32 (Spring 1995) (alteration in original).

49. John Oakley, Defining the Limits of Delegation, in 3 THE LONG TERM VIEW: A J. OF INFORMED OPINION 85 (Spring 1995). 
an interactive process. One Circuit judge noted, "Often you can do your best thinking by talking to someone about the case. They [the law clerks] have their view, you have your view, and by talking you are often able to develop your own thoughts a lot better than if you just try to puzzle out an issue on your own." 50

One of the judges who had served in the armed forces suggested that district court writing was akin to what the judge had learned as a military officer in the doctrine of "Completed Staff Work." Though the doctrine is not a perfect fit, the observation captures some of the ways judges at the district court work with a law clerk in writing. The "Completed Staff Work" doctrine encompasses the study of a problem and the provision of a solution by, in this instance, the law clerk. The work is done in such form that all that the judge has to do is to give approval or disapproval of the draft order or opinion:

The concept, completed action, is emphasized because the more difficult a problem is, the more there is a tendency to present the problem to the boss in a piecemeal fashion. It is the duty of a staff person to work out the details. The individual should not consult with the boss in the determination of these details, no matter how perplexing they may be. The individual may and should consult other staff people. The product, whether it involves the pronouncement of a new policy or affects an established one, should be worked out in finished formed [sic] before presentation to the boss for decision. ${ }^{51}$

While the doctrine is descriptive, there are few judges who follow it exactly because simply signing off on a clerk's work is viewed as an abdication of the judge's role. Where the doctrine may be significant is with those judges who do not regularly read all of the briefs or other materials filed in a case.

In summary, virtually all of the interviewed judges rely on law clerks to draft routine orders. These kinds of routine orders are usually discussed with the judge, or the judge uses the electronic docket himself or herself, to grant or deny. Judges with career clerks frequently have that clerk review everything before the judge sees it. None of the judges authorize a JA or law clerk to file any order before the judge's review and authorization. This is so despite the observation of one judge that law clerks are really junior judges: "The only thing they can't do is hold court and sign orders."

Chief Justice Vinson did his opinion writing "with his hands in his pockets." All of the interviewed judges recognized the near impossibility of scratch writing. Each recognized a career clerk is beneficial to the individual judge, because the career clerk enables the judge to discharge his or her work more efficiently. The judges interviewed acknowledged that a term clerk is less valuable to the judge in writing and other assignments until later in the clerkship term. The judges noted the risk of delegating the judicial function of making decisions as a constitutional officer and all the judges take steps to make sure that while "writing with [their] hands in [their] pockets" they are making the judgment and instructing the first draft scrivener. When interviewing the judges about whether

50. Alex Kozinski, Making the Case For Law Clerks: An Interview with Judge Alex Kozinski, in 3 THE LONG TERM VIEW: A J. OF INFORMED OPINION 55 (Spring 1995) [hereinafter Judge Kozinski].

51. See High Performing Sys., Inc., Completed StafF Work (August 2004), www.hpsys.com/pdfs/completed\%20staff\%20work\%20synopsis.pdf [https://perma.cc/HM5X-BT8P]. 
they had switched from term clerks to career, or the other way around, each expressed concern about abdicating the judicial function by relying too heavily on law clerks. The same is true of the non-switchers interviewed.

In conclusion, the subject of abdication and the role of law clerks has been much discussed and criticized. Various scholars "have challenged the clerkship institution on the ground that it permits law clerks to exercise too much control over the legal process. Challengers to this institutional practice argue that law clerks are writing judicial opinions and wielding an inappropriate level of influence over judicial outcomes." 52 Some have asked, "Is there a point at which delegation of responsibility to clerks crosses the line from undesirable to unconstitutional?" 53 Perhaps this question demands further study in light of the way some career clerks are used.

\section{Law Clerk Qualities}

A law clerk's position is viewed by judges as an office of public trust. In the hiring process, a judge makes a distinction between term clerks and those considered potential career clerks. From this perspective several judges ask when hiring a term clerk, "will this person be a trial lawyer?" and then mentor the term clerk to go into the world as a lawyer with qualities instilled by the judge. On the other hand, the career clerk must have the essential quality of being able to challenge the judge intellectually and must possess the skill and ability to tell the judge that the judge is wrong and to explain why. The term clerk should have this quality as well.

Judges want clerks with some life experience: persons who have worked outside the law; have military experience; or have experience with deadlines. ${ }^{54}$ They like to have clerks who are smarter than they are but recognize that the difference in the degree of judgment is experience. In this vein, career clerks do have more experience and are more likely to be in tune with the judge and so are able to provide better assistance and recommendations to the judge. They are in harmony. The term clerks do not play the same role as the career clerk in the deliberative colloquy with the judge. But, as the term clerks gain legal experience and expertise, the asymmetry of expertise between the term clerk and the career clerk lessens. ${ }^{55}$

Although any law clerk should have organizational skills and be able to get along well with others, judges look for different qualities in a term clerk than they do in a career clerk. A variety of characteristics were described by judges seeking term clerks, or altering the status of a term clerk to that of a career clerk. The qualities include someone who is really smart and who is a good writer. Judges

52. Peppers et al., supra note 6, at 629 (footnote omitted).

53. Chad Oldfather \& Todd C. Peppers, Introduction: Judicial Assistants Or Junior Judges: The Hiring, Utilization, And Influence Of Law Clerks, 98 MARQ. L. REV. 1, 6 (Fall 2014).

54. "All things being equal, someone who has more experience, who has done other things in life, has a leg up on other people applying for a clerkship." Judge Kozinski, supra note 50.

55. Swanson \& Wasby, supra note 7, at 37 . 
are averse to clerks, particularly career clerks, who are sycophants. When judges search for career clerks they want an honest clerk who is able to pleasantly disagree. The career clerk needs to have the ability to work well with others and should love the work. Furthermore, a career clerk should not be a bureaucrat, someone who is just in it for the pay check. A certain facility with technology and a desire to get the work right in valuing the administration of justice is also important. So is the quality of being a problem solver who loves to dig deep to find the answer, the important fact, or the controlling case, rule, or statute. Judges encourage career clerks to avoid being shy if they see a case or an issue from a different perspective than the judge. In essence, most district and magistrate judges interviewed want a career clerk who will be exceedingly competent as a devil's advocate in chambers.

The literature suggests that term clerks can be of higher quality than career clerks and that they bring a greater degree of freshness of thought to the court. Judges who switched from career to term clerks emphasized this quality. Through their freshness, term clerks provide an antidote to the professional isolation that a judge suffers when assuming the monastic mantel of the bench. Judges acknowledge the benefits of a career clerk in terms of familiarity with the judge and knowing how things get done. But even those judges who have had career clerks for a long time recognize the problem of abdication. The problem of career clerks is the judge's fear that the clerk will become the judge's alter ego, subject to less supervision and acquiring greater and greater authority in the operations of chambers. ${ }^{56}$ More problematic with the career clerk is a perception by the bar or the public that there is a role reversal between the judge and the clerk.

The choice judges make regarding the status of the law clerk is predicated on two different views of the judge's role. There is the mentoring model, where the judge has a duty to the bar and to newly minted lawyers to mentor law clerks but to avoid keeping them for extended periods. There is a professional service aspect of the judge's work with law clerks that suffers when the judge switches to career clerks. "[T]he clerk who has worked at the judge's elbow for a year or two will take that training to the next position in the legal profession, likely as a practicing lawyer and sometimes eventually as a judge. The profession and the common good will be advanced. $" 57$

A different view holds that the judge's duty to the bar and to litigants justifies retention of a career clerk. Because the career clerk is efficient and in tune with the judge, there is a benefit to the bar and to the litigants in having experienced judicial support. Whatever the purpose of the judge in switching to career clerks, career clerks should come from a court's term clerk alumni. This is consistent with a proposed Judicial Conference policy that would have required three years of term clerk experience before a clerk is eligible for career status. ${ }^{58}$

56. See OAKLEY \& THOMPSON, supra note 5, at 105.

57. Kearney, supra note 16 , at $15-16$.

58. See Summary of the Report of the Judicial Conference Committee on Judicial Resources, DT: Committee Report, CR-JUDRES-SEP 07 (September 2007). 


\section{Switching: Career vs. Term Clerks}

Regardless of how a judge chooses to staff his or her chamber at the beginning of their career, judges often switch between term and career clerks. The reasons for those switches can provide valuable insight into the ways judges use clerks: as bat boys, pinch hitters, or designated hitters. The interviews revealed some factors judges consider when choosing between term and career clerks. Each of the judges interviewed stated in one way or another that a significant aspect of choosing between term clerks or career clerks was wanting to have a clerk who knows how to avoid the mistakes of the "August Effect": the things the new term clerks don't know until they know what they don't know. The most common reason for the switch from term to career seems to be the intellectual vigor of the clerk, how well the clerk gets along with the judge and the judge's staff personality-wise, as well as the absence of an overt effort by the clerk to establish a chambers pecking order. The desire to switch from career to term reflects a concern that the career clerk, though smart and a good writer, begins to sense there is a pecking order in chambers. That, in turn, creates internal friction with the other clerks and interns/externs when the career clerk casts a "mini judge" shadow.

Another consideration in making the switch is the concern a judge has for clerks and their respective futures. Some career clerks, when they depart chambers, have a difficult time getting employment, particularly with the larger firms, because six, seven, or even ten years of clerking raises eyebrows. In addition, one of the interviewed judges who switched from career to term clerks advised that the fresh thinking of term clerks kept him on his toes. Having had career clerks for long periods, several judges felt that individual career clerks had turned into bureaucrats, mostly interested in the pay and hours and not very ambitious about the work. "[N]o matter how satisfied a court becomes with its complement of career clerks, it never [should] permit its judges to insulate themselves from short-term clerks altogether. A court which forsakes the shortterm clerk is a court which has forgotten - or worse, forsaken - the law clerk's highest purpose." ${ }^{59}$ Ultimately, switching from a term clerk to a career clerk is a serendipitous event. It is the confluence of intelligence, cooperation, writing and analytical skills, and most importantly a good working relationship. But, the switch from a career clerk to term is a conscious event principally based on chambers atmosphere.

The "August Effect" is another factor for judges to consider, whether they are hiring term or career clerks. There is far less hand-holding by the judge with a career clerk than there is with the term clerk. The career clerks serve the judge differently because they have longevity in the position, know the judge's way of thinking and are likely to capture the judge's voice in writing. When asked if an outsider could tell who an author was from any written opinion from a particular chambers, the judges with career clerks expressed the view that it would generally

59. OAKLEY \& THOMPSON, supra note 5, at 138 . 
not be possible. However, it was likely that if there was a zinger in the opinion it was from the judge's pen.

The general reasons that judges think a career clerk is more valuable rest on principles of continuity, a comfortable working relationship, and collaboration in writing, analysis, and expression. Furthermore, with the passage of time, the career clerks gain wisdom and fill the role of mentoring term clerks and interns/externs. A career clerk is more likely to be able to tell the judge he or she is incorrect and is not fearful of pointing out prior cases where the judge may have ruled differently on a similar issue because of the career clerk's institutional memory.

With the exception of complex matters, as discussed above, there is usually no difference in the quality of work between career clerks and term clerks except on the issue of judgment. The complexity of a case is primarily a concern when the case is likely to exceed the term clerk's time in chambers. Thus, most often the career clerk handles such matters for the judge. One judge adopted a policy on very close legal questions of having the term clerk write the opinion for one outcome while delegating to the career clerk an opinion coming out the other way.

A concern in making the transition from a two term clerk chamber to a career clerk and term clerk chamber is that at some point the career clerk is at risk of entitlement syndrome. ${ }^{60}$ As previously suggested, the concern is that a career clerk can get so comfortable that the clerk loses perspective. The judge needs to address this when making a decision to convert a term clerk into a career clerk.

One judge, who was a district judge but is now a circuit judge, felt that the district court clerkship is a more difficult job than an appellate clerkship. The judge's view was that appellate clerkships are an extension of law school academics, while the district court clerk needs to learn to multitask and must quickly learn to triage and balance deadlines and workload. The interviewed judges who ascribe to the view that their job is to mentor clerks, noted that a oneyear term is a good fit from the term clerk's perspective, but a two-year term is the best fit for the judge who employs a term clerk. Staggered term clerks means that the judge will always have a seasoned clerk. All of the interviewed judges who use staggered term clerks paid particular attention to mentoring term clerks and to learning about recent technology as well as current legal education.

Some interviewed judges have concerns about switching from term to career clerks based on observations of other judges in the same district who employed career clerks. Those judges often delegated the responsibilities of judging to the career clerks. This concern is a reason to thoroughly vet the career clerk concept.

60. There is a concern that a long-term relationship with a career clerk "breeds an atmosphere of too much equality and hence too much dependence on the clerk." OAKLEY \& THOMPSON, supra note 5, at 109. There is a concern by some judges that career status can "encourage judicial indolence." Id. at 126. 


\section{Balancing the Pros and Cons}

The "August Effect" is a core principle in the decision of a judge to go from term clerks to one or more career clerks. There are several different methods for staffing and dealing with the "August Effect" in the district court. Additionally, there are intertwined reasons to choose career or term clerks. I have coined descriptive terms for the various categories of law clerks that encompasses this discussion. First there is the "one and done" class. These are term clerks hired for one year. They come in late August and leave around the same time after one year of service. Several judges said this kind of clerkship seems best for the clerk. Even so, it is the kind of clerk that is least helpful to the judge. The second group is called "two and shoo." These are term clerks who serve the judge for two years. From the judge's perspective, two years is the ideal length of service for a term clerk. The two-year term clerk, after learning the ropes, provides the judge sound advice coupled with an enthusiasm and energy for the work. In trying to minimize the "August Effect," the district judge can look for term clerks who have experience clerking for another court or judge, or a person who has life experience. The third group is the career clerk. There are various advantages to employing a career clerk, but there is a concern when a career clerk is employed that the clerk becomes a "mini-judge" and an abdication of responsibility occurs. Each of the judges interviewed felt that the best working arrangement for a judge and law clerks was either staggered term clerks serving two-year terms, or one two-year term clerk and one career clerk. Those judges in the latter category emphasized continuity and energy, a combination fostered by the characteristics of the new clerk and the skills and abilities of the career clerk. The principal advantage to the judge is that the arrangement keeps new blood and enthusiasm in the judge's work. More importantly, it is a safeguard against abdication of the judicial function.

IV

\section{CONCLUSION}

\section{A. Are Career Clerks Designated Hitters?}

Much of the information revealed by the judges I interviewed seems without a negative connotation. It seems that the judge is a baseball manager who uses the career clerk as a designated hitter. The rules of baseball, however, do not authorize the unrestrained use of the designated hitter. Indeed, designated hitters are not a part of the National League except in the World Series. The analogy pops up in the views that judges have on the merits of career as opposed to term clerks.

Underlying the question is the "August Effect," the issue of inexperience and how that relates to chambers staffing. There are no universals among judges about the normative question of which kind law clerk is best. There is no doubt that a particular judge's view as to the answer is experience driven. Overall, the role of the clerk can be as a designated hitter (the career clerk who acts as a junior 
judge), the pinch hitter (the two year term clerk who works closely with the judge but has a more limited role), or the bat boy (the one year term clerk who only assists the judge and is of limited use by virtue of the brief time in chambers).

There is a difference at the outset in the role of the clerk and the judge depending on whether the Article III judge has served as a state trial judge or as a magistrate judge. In those instances the judge is more likely to do certain tasks without law clerk help, because the judge has had only one clerk or no law clerks to help in the work of the court. When it comes to writing, it is safe to say that very little writing is done in the first instance by any judge. Some judges, whether they have career clerks or term clerks look to the law clerk for guidance on issues that the judge must decide and not to the lawyer's briefing. While that happens whether the judge reads all of the briefings or not, there is a certain danger that the law clerk may lead the judge astray. Additionally, the judge can easily become too lazy and give the law clerk too much responsibility.

The baseball analogy is striking here, too. In the olden days, there were managers that also played. Maybe that is what most judges do in relation to their law clerks, all are a part of a team. On the other hand, currently the manager does not play and, at least in the American League, can only use the designated hitter in specific ways. Like a designated hitter, career clerks need to be used within the rules and never in place of judges.

\section{B. Reflections}

Often when one embarks on a quest to determine how something works, or why is it done a certain way, there is opportunity for self-reflection. Such is the case here. I have never had a career clerk, though I have had term clerks with whom I worked for more than three years. In listening to my colleagues as I interviewed them, I questioned my own practice. Maybe, as a senior district judge, it is time to slow the pace and ask one of my term clerks if he or she is interested in working as a career clerk. The enthusiasm, new ideas, and attitude that the new term clerk brings is something that I think I would miss. I would also face the dilemma of trying to figure out if I had told a "war story" or some joke to the career clerk before. With term clerks, there is the advantage of recycling stories and jokes every two years. 